\title{
ANOTHER MOdEst PROPOSAL
}

\author{
DESMOND MANDERSON ${ }^{*}$
}

\begin{abstract}
[In essays first published earlier this year in mainstream Australian media to considerable fanfare, Bagaric and Clarke, two Australian academics, develop a modest proposal for the justification of torture under exceptional circumstances. This essay rebuts the proposal and defends the absolute prohibition against torture. Their attempt to abstract torture from the social context - including the "war on terror" - in which the question of government sanctioned torture is now being raised, is condemned as ingenuous. A rhetorical analysis further demonstrates that the authors themselves do not believe their argument is either hypothetical or limited. Furthermore, when the actual "defence of torture" is examined, it is shown to be illogical, incoherent, and lacking any sophisticated understanding of the nature, purpose, or effects of torture. This is not the first time that half-baked reasoning and careless analogies have been developed in order to defend the indefensible. Drawing on Voltaire and Jonathan Swift as well as Guantanamo Bay, this essay puts an important social issue into its immediate and its larger historical context.]
\end{abstract}

\section{TORTURE IN THEORY}

François Marie Arouet was born in 1694 when the Old Regime - the iron fist of Louis XIV in the velvet glove of Versailles - seemed utterly impervious to change. Yet by the time of Arouet's death in 1778, the Enlightenment had wrought such a destabilizing effect upon the Regime that it had a scant ten years left to run. Writing

\footnotetext{
${ }^{*}$ Professor Desmond Manderson holds the Canada Research Chair in Law and Discourse in the Faculty of Law at McGill University, Montreal. Recent books include Songs Without Music: AESTHETIC DimENSIONS OF LAW AND JUSTICE (2000) and PROXIMITY: LEVINAS AND THE SOUL OF LAW (forthcoming).
} 
under the name Voltaire, ${ }^{1}$ Arouet, playwright, essayist, and critic, was an overwhelmingly important figure in the development of modern Western ideas about government and justice. Above all, he was a relentless fighter against cruelty and superstition. I doubt many would disagree with me when I say that we still have need of such fighters. But sometimes we find the advocates of cruelty and superstition in surprising places.

Voltaire's mantra throughout his long life, his battle cry against the enemies of Enlightenment, was the phrase "Écrasez l'infâme". ${ }^{2}$ "Wipe out this infamy - just erase it entirely". But what was so infamous as to demand utter obliteration? On one level, the Catholic church of his day; on another, the whole system of absolute government that held France, and most of Europe, in thrall. What they had in common was this: a power that was entirely unaccountable, entirely unlimited, and which instilled a climate of fear through calculated dosages of cruelty.

Voltaire had in mind in particular government practices of torture, both private and public, which were common in France. This barbarism sickened him and he knew that, father of the Age of Reason though he was, there was no reasoning with or controlling it. We cannot argue about such cruelty for that is already to dignify it as reasonable. We can only commit ourselves to destroying it. Écrasez l'infâme.

One of the cases that most profoundly disturbed Voltaire was the death of Damiens. Convicted of attempting to assassinate Louis XV, he was shockingly tortured and executed over several hours in the main square of Paris town hall. Michel Foucault wrote at length about this gruesome event, and used it as emblematic of the medieval world. ${ }^{3}$ Under the ancien régime, the power of the State was absolute, exercised through public spectacles and private terrors designed to establish the total control of the State and the total subjection that awaited those who resisted it. Torture, like the great castles and glorious processions of the monarchy, was a way of demonstrating that spectacular power.

Antiquity had been a civilization of spectacle. "To render accessible to a multitude of men the inspection of a small number of objects": this was the problem to which the architecture of temples, theatres and circuses responded. With spectacle, there was a predominance of public life, the intensity of festivals, sensual proximity. In these rituals in which blood flowed, society found new vigour and formed for a moment a single great body. ${ }^{4}$

\footnotetext{
1 Theodore Besterman, Voltaire (1969), Alfred Owen Aldridge, Voltaire and the Century of Light (1975). See also Roger Pearson, Voltaire Almighty: A Life in the Pursuit of FREEDOM (forthcoming).

2 Jim Herrick, Voltaire: Ecrasez L'Infame (1985). Voltaire, THE Portable Voltaire (Ben Ray Redman ed., 1949).

${ }^{3}$ Michel FouCAULT, Discipline AND Punísh (Alan Sheridan, trans., 1995).

${ }^{4}$ Id. at 216-7.
} 
Violence, says Foucault, above all attacks the State and its right to the exclusive legitimate use of it. The public execution performs the re-appropriation of that violence by the State, and makes the victim an agent of the complete reestablishment of the power of sovereignty. ${ }^{5}$ The very bodies of the tortured, such as Damiens, became mere puppets forcibly made to act a part in this pageant play of complete authority. The reduction of a person to a body and a body to the puppet of another's will, as much as pain, defines torture. Torture and execution "did not reestablish justice; it re-activated power". ${ }^{6}$ Its point, ultimately, was not to exact retribution or extract information, but to show us all just who was boss.

Yet ironically, as the case of Voltaire demonstrates, the very brutality of torture operates against this purpose. Many people became so horrified by events like the death of Damiens and by institutions like the lettres des cachets, which entitled the French State to lock their opponents up indefinitely, without trial, and without explanation, that torture and arbitrary punishment became imbued with a wholly different set of meanings than that intended by the State. It came to show not the power of the State, but its insecurity; to suggest not the divinity of the sovereign but his injustice; to instil not a kind of passivity and submission in the population but on the contrary to generate activity and resistance. These provocations exploded into life at the end of the eighteenth century, wiping out not just the infamous practices themselves but the regime that had become synonymous with them.

Now Foucault argues that since the Enlightenment power is exercised in quite different ways: not by the punishment of bodies but through the disciplining of minds; not through dramatic acts that destroy us absolutely but through tiny daily pressures that encourage us to conform; not in a public square and periodically, but every day in homes, schools, factories, armies, hospitals. The end of torture as a State institution was coupled by the rise of other institutions, less violent and more subtly committed to moulding "docile bodies".

But perhaps we have written off the ancien régime too quickly. Professor Mirko Bagaric and Julie Clarke, writing from the comfort of Deakin University School of Law, have attracted widespread media attention by arguing that torture is a "permissible" and "moral" action in certain circumstances. ${ }^{7}$ Within days, Peter Faris, one-time head of the now defunct National Crime Authority, was reported as supporting the "call". ${ }^{8}$ Government sanctioned torture is apparently back on the agenda.

\footnotetext{
${ }^{5}$ Id. at $48-49$.

${ }^{6}$ Id. at 49.

7 Mirko Bagaric \& Julie Clarke, The Yes Case Can Outweigh The No, Sydney Morning Herald, May 17 2005; Mirko Bagaric, A Case for Torture, The Age, May 17, 2005. See also Mirko Bagaric \& Julie Clarke, Not Enough Official Torture in the World? The Circumstances in Which Torture Is Morally Justifiable, 39 UNIVERSITY S.F.L. REV. (2005). My analysis is principally derived from the opinion pieces which were given considerable publicity in the Australian media and which convey their argument in concise terms.

${ }^{8}$ Torture Acceptable, Says Former NCA Chief, Sydney MoRning HeRALD, May 22, 2005.
} 
This issue is by no means hypothetical. We are familiar with the dismal story of Abu Ghraib. ${ }^{9}$ But it was by no means an isolated instance. In pursuit of the socalled "global war against terrorism", the United States has not only been involved in cases of torture themselves, but has routinely sent - the term used is "rendered" suspects to third countries in order that they might be tortured there. ${ }^{10}$ So too rumours of the kind of practices and calculated cruelties that take place at Guantanamo Bay have surfaced this year with worrying regularity.

Above all, the United States Government has over the past several years clearly indicated its desire to claim an absolute sovereignty befitting the Sun King. The Bush Administration insists on its right to act as it sees fit in the "war on terror", including by the use of torture and unconstrained by either domestic or international law. The Working Group Report on Detainee Interrogations in the Global War on Terrorism, authorized by Secretary of Defense Rumsfeld, argues that the President's "ultimate authority" in a time of self-proclaimed and self-defined war is not inhibited by any laws including United States statutes against torture. Consequently "the prohibition against torture must be construed as inapplicable to interrogations undertaken pursuant to his Commander-in-Chief Authority". ${ }^{11}$ Alberto Gonzales, at the time Legal Counsel to the White House, is on record as advising that the "new paradigm" of counter-terrorism "renders obsolete Geneva [Convention]'s strict limitations on questioning of enemy prisoners and renders quaint some of its provisions”. ${ }^{12}$ For his sins, Alberto Gonzales was appointed United States Attorney General in the second Bush administration. A legal black hole has been created in two ways. On the one hand, an untrammelled sovereignty is now claimed in interrogating terror suspects. On the other, the United States President has himself declared that the detainees at Guantanamo and elsewhere (over 70,000 people at last count) fall into no recognizable international category and are therefore uncovered by any international law. ${ }^{13}$ In the vacuum caused by the infinity of sovereignty and the nullity of its targets, anything is now possible.

Trained lawyers that they are, Bagaric and Clarke ignore this social context. They studiously protect themselves against allegations of their complicity in these trends.

\footnotetext{
9 Seymour M. Hersh, Torture at Abu Ghraib, THE New Yorker, May 10, 2004; MARK DANNER, TORTURE AND TRUTH: AMERICA, ABU GHRAIB, AND THE WAR ON TERROR (2004).

10 John Barry, Michael Hirsh and Michael Isikoff, The Roots of Torture, NEWSWEEK INTERNATIONAL, May 24, 2004; Jane Mayer, Outsourcing Torture, NEW YORKER, Feb. 14, 2005. See also US DEPARTMENT OF DEFENSE, WORKING GROUP REPORT ON DETAINEE INTERROGATIONS IN THE GLOBAL WAR ON TERRORISM: ASSESSMENT OF LEGAL, HISTORICAL, POLICY AND OPERATIONAL CONSIDERATIONS, Mar. 6, 2003; OfFICE OF LEgAL COUNSEL US DEPARTMENT OF JustiCE, Memorandum For Alberto R. Gonzalez, Counsel to the President, AND William J. Haynes II

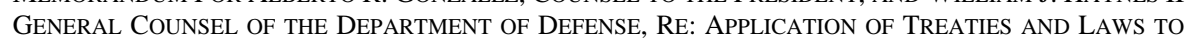
Al QAedA AND TALIBAN DetaineEs, Jan. 22, 2002. And see AMNESTY InTERnAtionAL, GuANTANAmo AND Beyond: The CONTINUING PURSuIT OF UnCHECKED EXECUTIVE POWER (REPORT ON THE UNITED STATES) (<www.amnesty.org >, 2005).

${ }^{11}$ US DEPARTMENT OF DEFENSE, supra note 10, at 20-21. See 18 USC § 2340A.

12 Alberto Gonzales, Memorandum for the President: DeCision RE APplication of the GENEVA CONVENTIONS ON PRISONERS OF WAR, Jan. 25, 2002.

${ }_{13}$ US White House, Memorandum: Humane Treatment of Al QAeda and Taliban DetaineEs, Feb. 7, 2002.
} 
Torture, they say, is only justifiable where "torturing a wrongdoer" "is the only means, due to the immediacy of the situation, to save the life of an innocent person". "Recent high-profile incidents of torture, apparently undertaken as punitive measures or in a bid to acquire information where there was no evidence of an immediate risk to the life of an innocent person, were reprehensible". Well isn't that nice to know. Moreover, the authors even concede that there may be no such reallife situations at all. So the question is presented as a harmless thought experiment designed to help us interrogate, and indeed to think more carefully about, our moral instincts. The effort taken to present their argument as theoretical rather than grounded in a specific event; and concomitantly as reasoned, rather than grounded in an emotional response, is central to the defensive strategy that underscores their analysis.

This attempt to escape responsibility for their words is complete nonsense. Is there a single victim of torture anywhere in the world who will be relieved to learn that the head of Deakin University Law School has at last injected a bit of sanity and balance into a terribly overwrought "debate"? Let us be clear about this: the only reason Bagaric and Clarke's article was worth publishing - in the University of San Francisco Law Review, and certainly on the opinion pages of The Age and the Sydney Morning Herald -- is because their subject is topical and relevant. Despite all their protestations to the contrary, their argument matters because, no matter how much they attempt to distance themselves from it, there is a real social context in which they have intervened. Can they seriously deny that their argument will be seized upon by those who wish to justify or practice torture around the world? Bagaric and Clarke refer to a hypothetical case in which the extraction of information from a suspect must be accomplished urgently to avoid the execution of a hostage; Peter Faris refers to the imminent explosion of a bomb. The very same hypotheticals were used by Attorney General Gonzales to justify discarding the Geneva Convention. "The nature of the new war places a high premium on other factors, such as the ability to quickly obtain information from captured terrorists and their sponsors in order to avoid further atrocities against ... civilians". ${ }^{14}$ Yet as we know, this "torture memo" encouraged the very practices that Bagaric and Clarke themselves judge "reprehensible". These practices include not only Abu Ghraib, ${ }^{15}$ but a wide range of interrogation techniques through which, according to Amnesty International's most recent report, the US government is even now engaging in torture dressed up in bureaucratic newspeak "in pursuit of unchecked executive power" ${ }^{16}$

The authors dismiss this as a "slippery slope" argument. But the use made of arguments like those of Bagaric and Clarke to justify ever-expanding practices of torture is not hypothetical but a demonstrable fact, engineered, according to US government sources, as part of "a calculated effort to create an atmosphere of legal ambi-

\footnotetext{
14 GonZALES, supra note 12.

${ }^{15}$ Hersh, supra note 9; DANNER, supra note 9.

16 AMNESTY INTERNATIONAL, supra note 10.
} 
guity". ${ }^{17}$ These Australian academics are seriously implicated in the creation of that atmosphere: that too is not just my fear or my opinion, but a fact. Just as we cannot understand what Voltaire meant by infâme without looking at the events to which he was responding, the context in which an argument is made must be read as part of its meaning. This is not a complex point. One is responsible not only for one's words but also for their necessary and predictable effects.

Neither do the authors themselves sincerely believe that the argument they make is either limited or purely hypothetical. They attack the "misguided", “alarmist", "reflexive", "absolutist" and "short-sighted" "moral indecency" of our belief that torture is always wrong. Poor Voltaire. He has been accused of many things, but rarely all at once. Whatever else we may say of Bagaric and Clarke, their argument is rich in emotion and rhetoric. True enough, they say that their defence of torture is so cautiously phrased that "a real-life situation where torture is justifiable [might] not eventuate". But in the very next paragraph they conclude: "the argument in favour of torture in limited circumstances needs to be made because it will encourage the community to think more carefully about moral judgments we collectively hold that are the cause of an enormous amount of suffering in the world". I wonder what hasty moral judgments they have in mind as being responsible for "enormous injustice and suffering"? The sole example they provide is our crazy, woollyheaded prohibition of torture. So this is what their argument must mean: the prohibition against torture is doing our society enormous harm not only in some hypothetical thought-world, but right now.

Even if we take Bagaric and Clarke's very modest proposal for torture at face value, it is logically inseparable from the real-world practices they disavow. Torture by its very nature deals with uncertainty; ignorance is the problem that it claims to solve through the exercise of violence. Yet torture produces such exceptionally unreliable information that it is generally thought to be useless. ${ }^{18}$ All Western legal systems acknowledge this by excluding, because of its inherent unreliability, evidence and confessions obtained through torture. ${ }^{19}$ But the authors do not once address their assumption that torture produces enough reliable information, enough of the time, to justify it. The central reason that Australian suspect Mamdouh Habib was recently released from US custody is that he had been tortured, and therefore any confession he had made was legally inadmissible in any court. ${ }^{20}$ Having been tortured, Habib could never be put on trial. Bagaric and Clarke provide no evidence as to why we should think that torture will produce good evidence. On the contrary, under current law, it produces no evidence at all.

Now let us look at the problem of ignorance and uncertainty from the torturer's point of view. A licensed torturer cannot know that a supposed terrorist (for example) is the only way to locate a bomb; or that there is a bomb; or that he will tell the

\footnotetext{
17 Barry, Hirsch \& Isikoff, supra note 11.

${ }^{18}$ For an historical understanding, see PAGE DU BoIs, TORTURE AND TRUTH (1991).

19 See for example UNITED NATIONS CONVENTION AGAINST TORTURE, Article 15.

${ }^{20}$ CBS NEWS, Jan. 11, 2005; SyDNEY MORNING HERALD, Jan. 11, 2005.
} 
truth; or even that he is a terrorist. The torturer suspects these things or rather he says he suspects these things, and of course he has every reason to say he suspects these things, because that is what justifies his actions. It is human nature to see the confused and ambiguous world in the way that is most convenient to us. Suppose our supposed terrorist denies knowing anything. Do we let him go... or torture him some more? When exactly do we stop? When exactly do we believe what the victim is telling us when the justification of torture is precisely that we only believe them when they tell us what we want to know, without already knowing it? If I have not put this point clearly it is because I can't. There is a paradox here which must lead to the kind of grey areas or "slippery slope" that Bagaric and Clarke attempt unsuccessfully to exclude. Given criteria under which torture is presumed acceptable, such as that which Bagaric and Clarke offer, the pressure on someone in a volatile and violent situation to see his enemy in a way that will justify torture is irresistible. The authors concede that their modest proposal may not lead to torture that saves a life. But they don't tell you the logical corollary: it will lead to torture, and therefore by their own reasoning it will lead to torture that does not save a life. Voltaire said, “doubt is not a pleasant condition, but certainty is an absurd one”. He was not wrong.

\section{TORTURe in Practice}

Bagaric and Clarke therefore cannot avoid considering the modern world, where torture is not so uncommon. In the real world, it is duplicitous to describe torture, as Bagaric and Clarke do, as "inflicting a relatively small level of harm on a wrongdoer". This must be some kind of joke. In the first place, there seems to be a real lack of understanding as to how the physical aspects of torture work. How effective would a regulated, prescribed, and "relatively small" dose of torture be? Torture is not like paying a parking fine. The terror and the threat of torture does not come only from the pain by itself. Many of us can tolerate a finite dose of pain, even if it is severe: ask a woman what childbirth is like. ${ }^{21}$ There is surely no reason to think that highly motivated terrorists would find the suffering of a specific "level of harm” impossible to bear. The power of torture, in most instances, comes instead from the promise that the torturer makes that the pain will not stop unless you talk. It is a logical contradiction to imagine that torture can be regulated, as Bagaric and Clarke seem to imagine, because it is part of its essence as torture that the victim is beyond protection and that resistance is futile. In addition, it is fundamental to its psychology that the torturer is the sole arbitrator of life and death. ${ }^{22}$ The whole power of torture comes from the absolute reduction of one party to pure power and the other to pure powerlessness. In short, and I believe this is a central point that the authors have not understood, torture gets people to talk (not, of course, to tell the truth, but certainly to talk) if and only if the torturer is sovereign. A torturer-cumbureaucrat is a contradiction in terms.

\footnotetext{
${ }^{21}$ See ERIC CASSEll, PAin AND Suffering (1993); ERIC CASSEll, The NATURE OF SufFering AND THE GOALS OF MEDICINE (1991).

${ }^{22}$ Elaine SCARRY, THE BODY IN PAIN: THE MAKING AND UNMAKING OF THE WORLD (1987).
} 
It is appalling that these lawyers - Faris too minimizes torture as "pulling out a fingernail” - trivialize the very practice they advocate. Perhaps Bagaric and Clarke have read nothing about the nature of pain, memory, and fear. ${ }^{23}$ Perhaps they have not read a single thing about the experience of torture and its implications on those who suffer it and those around them. ${ }^{24}$ Perhaps they just have no imagination. They do not appear to understand that torture is not simply pain. It is the experience of absolute powerlessness that reduces the victim, in their own eyes as well as their torturer's, to an animal, a body without will or dignity of any kind. It is the destruction of identity. Torture is rape just as rape is torture. It is not something to shrug off or even, most of the time, to get over.

Neither can we limit our analysis to a single tortured individual. In the world we live in and in which Bagaric and Clarke's argument actually matters, torture is never about the emergency rescue of an innocent life. It is used to extract a wide range of information about the functioning of many outlaw groups. But because of the inherent unreliability of its evidence, this is not its main purpose. Torture is used to punish and humiliate dissidents, terrorists, and members of ethnic minorities. It is used as a calibrated dose of cruelty through which to terrorize whole communities. $^{25}$ Just like Damiens, torture is a demonstration of what the State can do to you and what it can get you to do. The effect is to create a generalized fear about the infinite and random power of the State to destroy lives, and an intense sense of vulnerability in victim populations.

To try and talk about torture as an act practiced on isolated individuals without considering its effects on the families and societies around them, who all live under its constant and unavoidable shadow, is either foolish or duplicitous. Torture does not just affect individuals. It affects whole societies: it terrorizes them and ultimately, as we saw in Voltaire's Europe, the powerlessness it communicates shifts from passivity to rage. The turning point in the lives of many $\mathrm{Al}$ Qaeda operatives was their imprisonment and torture in Egyptian, Syrian, and other middle eastern prisons: this same Egypt to which the United States still "renders" suspects in order to soften them up. ${ }^{26}$ Torture produces terrorists: whole families and villages of them. That too is a necessary implication of even the apologists' pale fiction of torture. It is one reason that there is a growing suspicion that the prisoners in Guantanamo Bay - according to the Secretary General of Amnesty International, part of the "gulag of our times"27 - may never be released. How can they be? Bystanders or warriors, they are much greater risks to us now.

\footnotetext{
23 Id.

24 They might start with Peter Elsass, Treating Victims of TORTURE AND Violence (1997).

25 See for example, JOHN CONROY, UNSPEAKABLE ACTS, ORDINARY PEOPLE (2001).

26 Mayer, supra note 10. See also Human Rights Watch Reports for 2005, particularly in relation to Egypt, and Stephen Grey, America's Gulag, The New StATESMan, May 17, 2004.

${ }^{27}$ NEW YORK TIMES, May 26, 2005.
} 
To these real and necessary consequences, which our society would have to understand, accept, and somehow combat if we were ever to accept Bagaric and Clarke's argument, the authors have paid no attention at all.

\section{DEFENDING IT}

I have argued, first logically and then practically, that it is impossible to accept this modest proposal for torture as being confined to its own strict terms. We are inevitably led to imagine the actual physical and social consequences of such a principle. But for the sake of argument let us look a little closer at the ways in which Bagaric and Clarke attempt to defend an entitlement to torture. ${ }^{28}$ According to Bagaric and Clarke, the illegality of torture has only served, by its unnecessary absolutism, to drive it "beneath the radar screen of accountability"; legalization might "reduce the instances of it". It is difficult to see why this assertion would be true. Our societies are not without experience of legal torture. Was there less of it then? Moreover, the emotions that lead to real torture - fear, crisis, hatred - will not be reduced by legality. In what sense will "accountability" make a difference to these practices except to provide a helpful framework in which they can be organized, carried out and justified?

The radar argument sounds initially plausible: it is certainly true that illegality does not always work and sometimes only serves to make matters worse. ${ }^{29}$ This is particularly the case, for example, in relation to victimless crimes. But torture is hardly victimless. Let us look a little closer to see how the analogy falls down. With drug use or prostitution, the argument is that legalization will clean up the secretive conditions under which they operate and therefore not lessen their incidence but ameliorate their effects. In general, the scholars of what is called "harm minimization" do not dare to contend that a more open approach to drugs will lead to less use; only that it will dramatically improve the social and health conditions of users. ${ }^{30}$ But it is not the conditions under which torture is practiced that are the problem. Danger and pain are not a by-product of torture (as they are, for example, to a considerable degree a by-product of the current regime of drug prohibition); they are intrinsic to it. Were torture done in public, were it supervised by a qualified medical practitioner in a hygienic environment, were it made respectable - tell me, would any of this make torture better? Once again Voltaire comes to mind: "If we believe absurdities, we shall commit atrocities”.

The centre-piece of Bagaric and Clarke's defence offers as obvious example of begging the question as I have seen. They argue by analogy to "the right of self-

\footnotetext{
${ }^{28}$ I leave aside their criticism of the "slippery slope" argument which I have referred to above.

${ }^{29}$ I have written about this at considerable length elsewhere: see DESMOND MANDERSON, FROM MR SIN TO Mr Big: A History OF AUSTRALIAN DRUg LAWS (1993).

30 Alex Wodak \& Tim Moore, Modernising Australia’s Drug Policy (2001); Alex WodaK \& Ron Owens, Drug Prohibition: A Call for Change (1996); Drug Use in Australia: A Harm MinimiZATION APPROACH (Margaret Hamilton et. al, eds., 1998); HARM REDUCTION: A NEW DIRECTION FOR DRUG POLICIES AND PROGRAMS (Patricia Erikson et. al, eds., 1997).
} 
defence, which of course extends to the defence of another". Let us leave aside that rather hasty "of course" which is far from evident. Just as we are entitled to respond with violence to a murderous attack, they say, we are entitled to protect others; if the only way to protect them is by torturing somebody for information, then torture must be legitimate too. But the analogy falls down in at least three ways. First, the principle of self-defence recognizes a reality: when it's "him or me" a law that said I could not respond to an attacker would be simply unenforceable. ${ }^{31}$ Here the violence of torture is a choice deliberately made and carried out, and not purely responsive.

Secondly, their analogy assumes the only point it needs to prove. One can legally defend oneself; one can even kill an attacker if necessary; but what legal system has ever authorized a case of torture "in self-defence"? Why do the authors assume that self-defence, which is strictly limited to a direct, minimal and reasonable response to threat, ${ }^{32}$ is in any way equivalent to torture, which is by its very nature indirect and maximal? In fact, our societies have, at least since the Enlightenment, feared pain more than death, ${ }^{33}$ believed that human dignity requires absolute protection under all circumstances, and thought torture a more serious act than execution. Legal systems throughout the world outlawed torture long, long before capital punishment. In the United States, torture has always been contrary to the $8^{\text {th }}$ Amendment; it is the paradigmatic example of "cruel and unusual punishment". ${ }^{34}$ Yet the death penalty continues to be applied - as painlessly as possible. ${ }^{35}$ So clearly in the United States, and in fact throughout the world, it is generally considered worse to torture than to kill. Bagaric and Clarke think it obvious that if we can kill someone in self-defence, therefore it must be all right to torture them. But this is precisely what the absolute prohibition of torture rejects. It is not that Bagaric and Clarke could not make an argument against this orthodoxy. But they do not attempt to do so. They simply assert their position as self-evident. It is nothing of the kind.

There is a third, and to my mind even more important, way in which the analogy between self-defence and torture fails. Self-defence is about individual action, torture is about government action: the limits we believe ought to apply to each are not necessarily the same. There is a profound difference between individual acts of cruelty and a system of government-regulated torture. There is a difference between kidnapping and a government policy of taking Aboriginal children from their families. $^{36}$ There is a difference between murder - even mass murder - and genocide. ${ }^{37}$ The difference is the government sanction and the government power that stands

\footnotetext{
31 See Lon Fuller, The Case of the Spelunkian Explorers, 62 HARV. L. REV. 616 (1949).

32 VIRo V. THE QUEEN, (1978) 141 CLR 88; ZECEVIC V. DPP (VICTORIA), F.C. 87/027 (UNREPORTED High COURT OF AUSTRALIA, 1987).

33 See Philippe Ariès, The Hour of Our DeAth (1981).

${ }^{34}$ CONSTITUTION, AMENDMENT VIII (US); see Wilkerson v. Utah (1878) 99 US 130 (US).

${ }^{35}$ Gregg v. Georgia (1976) 428 US 153 (US).

36 See Kruger v. Commonwealth (1997) 190 CLR 1; HuMAN Rights AND EQUAL OPPORTUNITY COMMISSION, BRINGING THEM HOME: REPORT OF THE NATIONAL INQUIRY INTO THE SEPARATION OF ABORIGINAL AND TORRES STRAIT ISLANDER CHILDREN FROM THEIR FAMILIES (Chair: Sir Ronald Wilson, 1997).

37 GEORGE ANDREOPOUlOS, GENOCIDE: CONCEPTUAL AND HistORICAL DimENSIONS (1994).
} 
behind it in each case. ${ }^{38}$ Government action - law - carries a mark of legitimacy with it. Self-defence which leads to murder, or even revenge, might elicit our sympathy. But it is not the same thing as a government program which establishes, institutionalizes, organizes, and legitimizes torture. No matter how limited, torture is thereby made right in a way that no act of personal self-defence ever makes murder right. It seems a little surprising that one has to say this to members of a faculty of law. The standards we expect of governments are different from the behaviour we anticipate from individuals. We hold governments to higher standards for a reason.

So too, the reach and mechanisms of government power make torture a weapon from which no member of the community will feel immune. If the State could torture any one of us - they probably wouldn't, but they could - what sort of a society would we live in? Now Bagaric and Clarke attempt to avoid this problem by implying that torture would only effect the very few that in some sense deserved it. They insist that it is "verging on moral indecency" "to favour the interests of wrongdoers over those of the innocent". The word "wrongdoer" is used throughout their argument. Although it makes us feel morally superior to the victim of torture, it is another question-begging term, since the authors again simply assume that we can happily identify the wrongdoers. Perhaps they are only associates of terrorists, or family members; and in any case any torture that takes place will very probably precede a trial that might establish whether or not they are innocent. After all, as both Bagaric and Clarke along with Gonzales insist, the whole point of the argument in favour of torture is our need "to quickly obtain information from captured terrorists and their sponsors". ${ }^{39}$ So much for the rule of law: another suspicion of 'wrongdoing' has been miraculously converted into a certainty.

In the real world, which again I am sorry to have to bring up, there are many reasons why we might all live in fear of a government which had reserved to itself some kind of right to torture suspects. Perhaps it might just be a case of mistaken identity, or maybe you happened to be born with a foreign sounding name, or maybe you look suspicious or are the wrong colour, or come from a country with a violent history, or are otherwise associated with the wrong people, or perhaps you were just known for holding unpopular opinions at one time or other. How much torture might it take to clear your name? In the face of all these nagging fears, would even a Professor at a law school feel truly safe? And what effect would that endemic, nagging fear have on all our lives and our relationship to the State? Peter Faris, former head of the National Crime Authority, says it would be all right "to pull out a fingernail of a terrorist in order to save a couple of million lives”. But the government legitimization of torture, whatever the reason, would ultimately serve only to cripple a few million lives.

\footnotetext{
38 An argument which, in relation to genocide, I have developed further in Desmond Manderson, Apocryphal Jurisprudence, 26 AUSTRALIAN J.L.P. 27 (2001).

${ }^{39}$ GONZALES, supra note 12.
} 


\section{OPPOSING IT}

The apologists cannot see the difference between self-defence and torture because they are concerned only about outcomes and never about means. For Bagaric and Clarke, it is simply a calculation: one tortured terrorist versus an innocent life or many. Their argument is a rather crude example of utilitarianism, ${ }^{40}$ except for the fact that they have not seriously attempted to take into account the actual costs and benefits of the balancing act they propose. In their version of the utilitarian calculus, the benefits are a sheer fantasy and the costs are completely ignored.

Against utilitarianism, there is not much to say that has not been said many times before. Ethics means that there are some things you do not do even though it would advantage you (or the whole society) to do them. Ethics means that we impose limits on our actions which cannot be reduced to a calculation about winners and losers. Slavery, for example, would not be less wrong if more people gained from it than lost. It would not be less wrong even if we only enslaved "wrongdoers". The wrong is intrinsic and irredeemable. It is not negotiable in terms of costs and benefits. $^{41}$

So too, human rights protect not just good people but all people, and not just some of the time but all of the time: they are not to be weighed up, or sacrificed. It is in the nature of a human right that it is incalculable. We might feel that certain people have acted in such a way that they no longer deserve to be treated humanely, and if society as a whole were to gain by torturing them a little, then we should be allowed to do so. But human rights are not something we deserve. They are something that protects each of us from abuse by protecting us all of us unconditionally. These rights recognize as inviolable the core of our autonomy as human beings, regardless of the temptation or the need to violate them. And as partial and problematic as this argument undoubtedly is, ${ }^{42}$ if there is anything at all that we have a right to protect against the government and against all of society, it is our bodily integrity, indeed our sanity, our very self. That is the absolute right of which torture threatens to deprive us. Rather more than a fingernail is at stake.

Torture is wrong under all circumstances, not because it leads to certain bad outcomes, but for no reason: simply and inherently. This is not a perverse argument.

\footnotetext{
40 J. S. Mill, Utilitarianism (George Sher, ed., 2001); Peter Singer, Practical Ethics (2d ed. 1993).

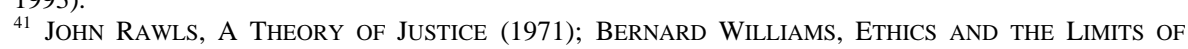
PHILOSOPHY (1985).

42 Douzinas, The END OF Human Rights (2000); MARTHA NuSSBAuM, WOMEN AND HuMAN DEVELOPMENT: THE CAPABILITIES APPROACH (2000).
} 
Love, for example, is good not because it might lead us to wealth or happiness, but for no reason. ${ }^{43}$ It just is. In fact, to look for reasons, to ask "what is love good for" ' or "how does loving someone benefit me"? is a sign of psychopathy. If Bagaric and Clarke, and Faris, cannot see the inherent wrong of torture, it is hard to see how to communicate with them. But let me suggest two possible approaches intended to communicate what I see as intrinsically true to those who clearly don't see it that way.

The first approach is literary. When Voltaire was a relatively young man, Jonathan Swift, author of Gulliver's Travels, wrote “A Modest Proposal” of his own. ${ }^{44}$ What will we do about the poor children of Ireland, he asked, who are such a burden to their parents?

I have been assured by a very knowing American of my acquaintance in London, that a young healthy child well nursed is at a year old a most delicious, nourishing, and wholesome food, whether stewed, roasted, baked, or boiled; and I make no doubt that it will equally serve in a fricassee or a ragout.

There's a solution to famine for you, and what after all is wrong with it? If children seem too innocent, we could just eat those in the reformatories, wrongdoers each and every one. Without a sense of our limits, the calibration of costs and benefits is unstoppable: and we shall be led to commit atrocities. It strikes me that the current modest proposal for torture makes the same mistakes: slipping seamlessly and without argument across fundamental distinctions, attempting to rationalize a repugnant argument, ignoring the social context it echoes and blind to the horrific practical implications of the system it envisages. But Swift's modest proposal was satire, while Bagaric and Clarke’s is farce.

The second approach is historical. Both proposals, above all, display that dangerous human quality of arrogance which somehow assumes that we can and should weigh up a person's pain or a community's fear, against a life or lives. It is the economists' approach to life and the tyrant's approach to politics: everything is about numbers, and no calculation is too dangerous to be attempted. This offers an easy answer to all our problems, but the easy answers are usually wrong. We know all about the Western history of State-sanctioned torture, l'amende honorable and the Inquisition. It is not a tradition worth reviving.

Finally, our repugnance is not simply the instinctive and "reflex rejection of torture" that Bagaric and Clarke disparage. A great deal of effort and thought has been expended towards making torture as unacceptable as it is today. We have learnt this feeling of disgust as a response to torture over time, and it is rather easier to argue

\footnotetext{
${ }^{43}$ See EMmanuel LeVINAS, TOtAlity AND Infinity (trans. Alphonso Lingis, 1969); OtHERWISE THAN BEING (trans. Alphonso Lingis, 1981); DESMOND MANDERSON, PROXIMITY: LEVINAS AND THE SOUL OF LAW (forthcoming).

44 JonAthan SWIFT, A Modest Proposal AND OTHER SATIRICAL WORKS 1729 (2002).
} 
that the world might benefit from more of it than less. Disgust, like shame, is not a pointless emotion. On the contrary, it is an exceptionally powerful way to change the behaviour of people and of communities. ${ }^{45}$ Voltaire would weep to read the arguments now being used to justify a new-found tolerance of torture. He saw torture and he knew what it looked like. And he also knew that at some point the arguments must stop so that the disgust might begin. Écrasez l'infâme. Don't negotiate: just wipe it out.

\footnotetext{
45 Martha Nussbaum, Hiding from Humanity: Disgust, Shame and the Law (2004); John BRAITHWAITE, CRIME, SHAME, AND REINTEGRATION (1989).
} 